\title{
İrade Bozukluğu Hallerinden Korkutmanın Hukuka Aykırılığı
}

\author{
The Illegality of Intimidation of Defective Intention
}

\section{Mehmet Özgür Avc1 ${ }^{*}$ (iD}

\section{öz}

Korkutmanın varlığı açısından öncelikle iradesi sakatlanan kişi tehdide uğramış olmalıdır. Tehdidin hukuka aykırılığından anlaşılması gereken kişinin karar verme özgürlüğüne müdahale etmenin hukuka aykırı olmasıdır. Bir hakkın veya kanundan doğan yetkinin kanunun öngördüğü kapsam ve yöntemle kullanılması durumunda hukuka aykırılık söz konusu olmaz. Bir hakkın veya kanundan doğan yetkinin kullanılacağı tehdidinin bu tehdit altında sözleşmeyi yapan kişinin kendisine yöneltilmiş olması gerekir. Bir hak ya da kanundan doğan yetkinin kullanılmasının hukuka aykırılığa neden olan husus tehdit edenin aşırı menfaat sağlamasıdır. Tehdit eden, tazminat borcundan kurtulmak suretiyle de aşırı menfaat sağlayabilir.

Anahtar Kelimeler: Tehdit, Hukuk Aykırılık, Hak, Kanundan Doğan Yetki, Aşırı Menfaat

\section{ABSTRACT}

In terms of the existence of intimidation, first of all, the person whose will is injured must have been menaced. What should be understood from the illegality of the menace is that it is unlawful to interfere with the freedom of decision of the person. If a right or legal authority is used with the scope and method stipulated by the law, there will be no illegality. The menace of exercising a right or a legal authority must be directed against the person making the contract under this menace. What causes the illegality of exercising a right or legal authority is the excessive benefit of the minatory. The minatory can also benefit excessively by getting rid of the debt of compensation.

Keywords: Menace, Illegality, Right, Legal Authority, Excessive Benefit

\section{Giriş}

Türk Borçlar Kanununda (TBK) “irade bozuklukları” başlığı altında düzenlenen "korkutma” kişinin sözleşme yapma hususundaki iradesinin özgür bir şekilde oluşmasına engel olan durumlardan biridir. TBK m. 37'de korkutmanın hüküm ve sonuçlarına; TBK m. 38'de ise kokutmanın şartlarına yer verilmiştir.

TBK m. 38’e göre, korkutulan, içinde bulunduğu durum bakımından kendisinin veya yakınlarından birinin kişilik haklarına ya da malvarlığına yönelik ağır ve yakın bir zarar tehlikesinin doğduğuna

* Dr. Öğr. Üyesi, Marmara Üniversitesi Hukuk Fakültesi Medeni Hukuk Anabilim Dalı

Sorumlu Yazar/Correspondence Author: Mehmet Özgür Avc1

E-posta/E-mail: mavci@marmara.edu.tr, 
inanmakta haklı ise, korkutma gerçekleşmiş sayılır (f.1). Bir hakkın veya kanundan doğan bir yetkinin kullanılacağı korkutmasıyla sözleşme yapıldığında da bu hakkı veya yetkiyi kullanacağını açıklayanın, diğer tarafın zor durumda kalmasından aşırı bir menfaat sağlamış olması halinde, korkutmanın varlığı kabul edilmektedir (f.2).

Bu maddenin ilk fikrasında kokutmanın genel şartları düzenlenmiş; ikinci fıkrasında ise bir hakka ya da kanundan doğan yetkinin kullanılmasına dayanan kokutmanın özel şartlarına işaret edilmiştir.

Korkutma sebebiyle sözleşmeyle bağlı olmadığını iddia eden kişinin kokutmanın şartlarının varlığını ispat etmesi gerekir. Bu şartlardan biri de kokutmanın hukuka aykırı olmasıdır. Bu çalışmada korkutmanın hukuk aykırı olması şartı, TBK m. 38/f.1 ve TBK m. 38/f.2 hükümleri açısından, konuya ilişkin yargı kararlarına da yer verilmek suretiyle incelenmiştir.

\section{Korkutma Kavramı}

Korkutma, sözlük anlamı itibariyle, bir kimseyi istediği şeyi yapmamaya, yapmamak istediği şeyi yapmaya korkutarak zorlamak ${ }^{1}$, bir hukuki muamele icrası zımnında bir kimsenin iradesi üzerine cebren tesir yapmak ${ }^{2}$ anlamlarına gelmektedir. TBK m. 37'de korkutmanın hüküm ve sonuçları, TBK m. 38'de korkutmanın şartları düzenlenmiş ancak korkutmanın tanımı yapılmamıştır³.

Öğretide ve yargı kararlarında korkutma, genel olarak hukuka aykırı bir şekilde yapılan tehdit ile bir kişide bir kötülüğe uğrayacağı kanaati uyandırılarak, onun sözleşme yapmasının sağlanması olarak tarif edilmektedir ${ }^{4}$.

1 Yılmaz, Ejder, Hukuk Sözlüğü, Ankara 2006, s. 305.

2 Türk Hukuk Lugatı, 3. Bası, Ankara 1991, s. 154-155.

3818 sayılı Borçlar Kanunu m. 29-31'de “ikrah” terimi kullanılmıştı. “İkrah”, cebir ve tehdit kullanarak kişiyi rıza göstermeyeceği bir söz veya davranışa zorlamak anlamında kullanılan bir fikıh terimidir., https://islamansiklopedisi.org. tr/ikrah; "Sözlükte istememek, rıza göstermemek anlamındaki kürh (kerh) kökünden türeyen ikrah, kişiyi razı olmadığ bir işi yapmaya zorlamak manasına gelir. Hatta kelimenin kök anlamında bir ayırım yapılarak kürhün insanın kendi tab’ından veya aklından kaynaklanan bir hoşlanmama, kerhin ise hariçten gelen bir zorlamanın yol açtığı meşakkat anlamı taşıdığı, sonradan dini bir terim haline gelen "mekruh'un birinci anlamla, ikrahın da ikinci anlamla daha sıkı bağının olduğu belirtilir. Dini literatürde de ikrah bu çerçevede terim anlamı kazanmış, kelam ilminde iman veya inkara zorlanmanın dini hükmü, fikıhta da bir kimseyi, serbest kaldığında razı olmayacağı ve istemeyeceği bir işi yapmaya zorlamanın dini ve hukuki sonuçları tartışılırken sıkça kullanılan bir terim olmuştur. Zorlayana mükrih, zorlanan kimseye de mükreh denilir.", Bardakoğlu, Ali, "İkrah”, Türkiye Diyanet Vakfı İslam Ansiklopedisi, 22. Cilt, İstanbul 2000, s. 30 .

4 von Tuhr, Andreas/Peter, Hans, Allgemeiner Teil des Schweizerischen Obligationenrechts, Band I (mit Supplement) 3. Auflage, Zürich 1984, s. 325; Etter, Josef, Die Furchterregung nach schweizerischem Obligationenrecht, Freiburg 1954, s. 35; Bucher, Eugen, Schweizerisches Obligationenrecht, Allgemeiner Teil, 2. Auflage, Bern 1988, s. 225; Schmidlin, Bruno, Berner Kommentar zum schweizerischen Privatracht, Obligationenrecht, Allgemeine Bestimmungen, Mängel des Vertragsabschlusses, Art. 23-31 OR, 2. Auflage, Bern 2013, Art. 29/30, N. 3 vd.; Basler Komm. OR I/Schwenzer, Honsell, Heinrich/Vogt, N. Peter/Wiegand, Wolfgang (Hrsg.), Basler Kommentar, Obligationenrecht I, Art. 1-529 OR, 4. Auflage, Basel 2007, Art. 29, N. 3; Gauch, Peter/Schluep, Walter R./Schmid, Jörg, Schweizerisches Obligationenrecht, Allgemeiner Teil, Band I, 10. Auflage, Zürich 2014, s. 200, N. 874; Schwenzer, Ingeborg, Schweizerisches Obligationenrecht, Allgemeiner Teil, 7. Auflage, Bern 2016, N. 38.14; Eren, Fikret, Borçlar Hukuku Genel Hükümler, 25. Baskı, Ankara 2020, s. 453, N. 1234; Oğuzman, M. Kemal/Öz, Turgut, Borçlar Hukuku Genel Hükümler, Cilt1, Güncellenip, Genişletilmiş 18. Bası, İstanbul 2020, s. 119, N. 364; Tekinay, S. Sulhi/ Akman, Sermet/Burcuoğlu, 
TBK m. 38/f.1'de bir sözleşmenin korkutmanın etkisi altında yapıldığının kabulü için gerekli olan şartlar belirtilmiştir. Bu hükme göre, "Korkutulan, içinde bulunduğu durum bakımından kendisinin veya yakınlarından birinin kişilik haklarına ya da malvarlığına yönelik ağır ve yakın bir zarar tehlikesinin doğduğuna inanmakta haklı ise, korkutma gerçekleşmiş sayılır”.

Bu fikrada belirtilen kokutmanın şartlarına kısaca bakılacak olursa, sözleşmenin geçerliliğini etkileyen bir korkutmadan bahsedebilmek için öncelikle iradesi sakatlanan tarafın bir tehdide uğramış olması gerekir. İrade beyanında bulunmadığı takdirde kötülüğe uğrayacağı kanısını bir kimsede uyandırmak için söylenen sözler ve davranışlar tehdit teşkil eder ${ }^{5}$. Yapılan tehdit, ağır ve yakında gerçekleşecek bir tehlikenin mevcut olduğu kanısını uyandırmalıdır. Önemsiz veya ileride gerçekleşecek tehlikelere ilişkin tehditler korkutma teşkil etmez ve sözleşmenin geçerliliğini etkilemezler. Tehditte belirtilen tehlike karşı tarafın şahsına veya yakınlarına yönelik olmalıdır. Tehlike, kişinin veya yakınlarının kişilik haklarına (hayatına, vücut tamlığına, namusuna) veya malvarlığına yönelik olabilir. Tehdit hukuka aykırı olmalıdır. Bir hakkın veya kanuni yetkinin kullanılması söz konusu olmadıkça tehdit hukuka aykırı olduğu gibi bir hakkın veya kanuni yetkinin kullanılacağı tehdidinin tehdit olunan için yarattığı güç durumdan aşırı menfaat elde etmek üzere yararlanılmışsa yapılan tehdit gene hukuka aykıııdır (TBK m. 38/2). Sözleşme, tehdidin yarattığı korku sonucu yapılmış olmalıdır. Bu korku yaratılmasaydı tehdide uğrayan taraf sözleşmeyi hiç yapmayacak idiyse veya sözleşmeyi başka şartlarda yapacak idiyse bu illiyet bağının varlığı kabul edilir6́.

Haluk/Altop, Atilla, Tekinay Borçlar Hukuku Genel Hükümler, Yeniden Gözden Geçirilmiş ve Genişletilmiş Yedinci Baskı, İstanbul 1993, s. 449; Kocayusufpaşaoğlu, Necip/Hatemi, Hüseyin/Serozan, Rona/Arpacı, Abdülkadir, Borçlar Hukuku Genel Bölüm, Birinci Cilt, Prof. Dr. Necip Kocayusufpaşaoğlu Borçlar Hukukuna Giriş Hukuki İşlem Sözleşme, Yenilenmiş Genişletilmiş Tamamlanmış 4 üncü Bası'dan 7 inci Tipkı Bası, İstanbul 2017, s. 473, N. 1; Antalya, O. Gökhan, Marmara Hukuk Yorumu, Borçlar Hukuku Genel Hükümler, Cilt V/1,1, Temel Kavramlar Sözleşmeden Doğan Borç İlişkileri, Genişletilmiş 2. Baskı, Ankara 2019, s. 406, N. 1765; Tercier, Pierre/Pichonnaz, Pascal/Develioğlu, H. Murat, Borçlar Hukuku Genel Hükümler, 2. Baskı, İstanbul 2020, s. 286, N. 893; Nomer, Haluk N., Borçlar Hukuku Genel Hükümler, Gözden Geçirilmiş, Genişletilmiş 17. Bası, İstanbul 2020, s. 104, N. 67; YHGK, E. 2004/3-192, K. 2004/174, T. 31.3.2004, Kazancı İçtihat Bilgi Bankası; Yarg. 3. HD, E. 2000/10569, K. 2000/10864, T. 16.11.2000, Kazancı İçtihat Bilgi Bankası.

5 Oğuzman/Öz, s. 120, N. 366; Yavuz, Nihat, Borçlar Hukuku El Kitabı, Ankara 2018, s. 196. Tehdit, korkutulmak istenen kişinin iradesinin baskı altına alınmasında kullanılan bir araçtır. Tehdit eden kişinin amacı, karşı tarafın iradesinin oluşum sürecine etki ederek, onun kendi istediği sonuca göre iradesini açıklaması ve bu iradeye göre sözleşmenin kurulmasını sağlamaktır., Demirbaş, Harun, Türk Borçlar Kanunu’nda Korkutmanın (İkrahın) Şartları ve Sonuçları, Yayımlanmamış Doktora Tezi, İÜSBE, İstanbul 2012, s. 5.

6 Korkutmanın şartlarına ilişkin ayrıntılı açıklamalar için bkz. Demirbaş, s. 37 vd.; Köroğlu, Emre, Türk Borçlar Hukukunda İrade Bozukluğu Hallerinden Korkutma, İstanbul 2020, s. 80 vd.; “... Bilindiği üzere, 6098 Sayıl Türk Borçlar Kanunu’nun (TBK) 37. (818 Sayll Borçlar Kanunu’nun (BK) 29.) maddesine göre, bir kimse karşı tarafın veya üçüncü bir kişinin kendisi veya yakınlarının maddi veya manevi varlğına yönelik hukuka aykırı ve esash korkutması sonucu yaptı̆̆ı sözleşme ile bağh sayılamaz. TBK’nın 38. (BK’nın 30.) maddesinde belirtildiği gibi, korkutmadan(ikrahtehdit) söz edilebilmesi için, korkutmanın sözleșmeyi yapan kimsenin veya yakınlarının kişilik haklarına veya mal varlkklarına yönelik olması, korkutmaya maruz kalanın sübjektif durumuna göre ağır ve derhal meydana gelebilecek nitelik taşıması, haksız(hukuka aykırı) sayılması, illiyet bağının bulunması yani sözleşmenin korkunun yarattığı etki sonucu yapılması zorunludur. Bu koşulların varlğ̆ halinde iradesi sakatlanan taraf, isterse iptal hakkını kullanmak suretiyle hukuki ilişkiyi geçmişe etkili(makable şamil) olarak ortadan kaldırılabilir. Hemen belirtmek gerekir ki, iptal hakkının kullanılması hiçbir şekle bağll değildir. Korkunun kalktı̆̆ı tarihten itibaren bir yıllık hak düşürü̈ü süre içerisinde sözleşme karşı tarafa yöneltilecek tek taraflı sarih ve zımni bir irade açıklaması ile feshedilebileceği gibi def'i veya dava yoluyla da kullanılabilir(TBK’nın 39. md).", Yarg. 1. HD, E. 2016/3874, K. 2019/3862, T. 17.6.2019, Kazancı İçtihat Bilgi Bankası. 
Korkutmayla bağlantılı bir kavram olan “cebir (zorlama)", bir kişinin iradesi dışında bir şey yapmaya ya da yapmamaya zorlanmasıdır ${ }^{7}$. Korkutmada kişiye istemediği, arzu etmediği halde bir şey yapması hususunda baskı yapılması söz konusudur. Cebir, maddi cebir ve manevi cebir olarak ikiye ayrılır ${ }^{8}$. Maddi cebirde kişinin iradesi tamamen devre dışı bırakılmakta onun yerini cebir kullanan kişinin iradesi almaktadır. Cebirde bulunan kişi, karşı tarafın davranışlarını kontrol altına alarak onu istediği gibi yönlendirmektedir. Örneğin, bir kişinin eli tutularak senet imzalatılmasında ya da parmağının imza yerine bastırılmasında maddi cebir vardır. Maddi cebire maruz kalan kişinin irade beyanı yok hükmündedir, sözleşme kurulmamıştır ${ }^{9}$. Bu sebeple, maddi cebir uygulanarak yapılmış olan sözleşmeler açısından TBK m. 37 ve 38 hükümleri uygulama alanı bulmaz ${ }^{10}$.

Manevi cebirde ise kişinin iradesi bulunmakla birlikte uygulanan baskı ile onun istenilen şekilde davranması sağlanmaktadır ${ }^{11}$. Örneğin kişinin başına silah dayayarak ya da yakınlarının tehlikeye maruz kalacağını belirterek, onu sözleşme yapmaya zorlamada kişi arzu etmediği halde bir sözleşme yapmaktadir ${ }^{12}$.

Manevi cebirde maddi cebirden farklı olarak kişide "eylem iradesi” bulunmaktadır. Cebir uygulayan kişinin davranışının zorlayıcı etkisi karşı tarafın kararını ortadan kaldırmamakta, manevi cebre uğrayan kişinin sözleşme kurmaya yönelik irade açıklaması bu kararın neticesi olarak ortaya çıkmaktadır ${ }^{13}$. TBK m. 37 ve 38 hükümleri manevi cebirin uygulandığı hallerle sinırlı olarak uygulanır ${ }^{14}$.

7 Yılmaz, s. 119; Köroğlu, s. 50.

8 Saymen, Ferit H./ Elbir, Halid K., Türk Borçlar Hukuku, Umumi Hükümler, C. I, İstanbul 1958, s. 274; Eren, s. 453, N. 1237; Esener, Turhan/Gündoğdu, Fatih, Borçlar Hukuku I, Sözleşmelerin Kuruluşu ve Geçerliliği (TBK m.1-48), İstanbul 2017, s.163.

9 von Tuhr/Peter, s. 325; Bucher, s. 224; Etter, s. 30; Basler Komm. OR I/Schwenzer, Art. 29, N. 1; Akyol, Şener, Borçlar Hukuku Genel Hükümler I, İstanbul 1995, s. 302; Kocayusufpaşaoğlu/Hatemi/Serozan/Arpac1, s. 473, N. 2; Saymen/ Elbir, s. 275; Antalya, s. 406, N. 1766; Tekinay/Akman/Burcuoğlu/Altop, s. 449; Esener/Gündoğdu, s. 163-164; Eren, s. 453-454, N. 1237; Özkaya, Eraslan, Yanılma-Aldatma-Korkutma Davaları (Hata-Hile-İkrah Davaları), Güncellenmiş 4. Baskı, Ankara 2019, s. 392.

10 Schmidlin, Art. 29/30, N. 4; Schwenzer, s. 298, N. 38.14.

11 von Tuhr/Peter, s. 325; Saymen/Elbir, s. 275; Akyol, s. 298; Tekinay/Akman/Burcuoğlu/Altop, s. 449.

12 Maddi ve manevi cebirde kişinin bir davranışta bulunmaya zorlanması, onun bedeni üzerindeki fiziksel temasa dayanabilir. Bu durumda bir ayrım yapılırken, kişinin davranışının kendi iradesine dayanıp dayanmadığı dikkate alınır. Fiziksel güç uygulanarak ya da söz söylenmesi, yazı, resim veya işaret gösterilmesi vb. şekillerde korkutulan kişi istememesine rağmen kendisi bir irade beyan ediyorsa manevi cebir, kişinin bedeni üzerinde salt fiziksel güç kullanılmak suretiyle onun irade beyan etmesi sağlanıyor ise maddi cebir söz konusudur. Maddi cebirde kişinin davranışı kendi iradesinin sonucu değildir., Demirbaş, s. 7.

13 von Tuhr/Peter, s. 325; Basler Komm. OR I/Schwenzer, Art. 29, N. 1; Tekinay/Akman/Burcuoğlu/Altop, s. 449; Kocayusufpaşaoğlu/Hatemi/Serozan/Arpacı, s. 473, N. 1; Schwenzer, s. 298, N. 38.14; Özkaya, s. $392-393$.

14 Schwenzer, s. 298, N. 38.14; Eren, s. 453, N. 1237; Kocayusufpaşaoğlu/Hatemi/Serozan/Arpac1, s. 473, N. 2; Antalya, s. 406, N. 1766; Akyol, s. 300; İstanbul Şerhi/Kurşat, İstanbul Şerhi, Türk Borçlar Kanunu, Yürürlük Kanunu, Cilt - 1 (Madde 1-82), İstanbul 2019, m. 38, N. 8; Köroğlu, s. 51. TBK m. 38/f.1'de “...ağır ve yakın bir zarar tehlikesinin doğduğuna inanmakta haklı ise...” ve TBK m. 37/f.1'de "taraflardan biri... sözleşme yapmışsa..." ifadeleri yer almaktadır. Bu ifadelere göre, tehlikeye uğrayacağı tehdidiyle korkutulan kişi üzerinde oluşturulan psikolojik baskıyla sözleşmenin kurulması durumunda korkutmadan söz edilir. Bu psikolojik baskıdan bir sözleşmenin kurulmasında araç olarak yararlanılması, bu baskı ve zorlamanın maddi değil, manevi olduğunu göstermektedir., Demirbaş, s. 10. 
Bu açıklamalar çerçevesinde korkutma, bir kişiye hukuka aykırı ve kasten manevi bir baskı uygulamak suretiyle, onun ya da yakınlarından birinin kişilik hakkına ya da malvarlığı değerlerine yönelik ağır ve yakın bir tehlikeye maruz kalacağının açı ya da örtülü biçimde bildirilerek, o kişinin sözleşme yapmasını sağlamak olarak tanımlanabilir ${ }^{15}$.

\section{Korkutmanın Hukuka Aykırı Olması}

OR Art. 29 Abs. l'de korkutmanın hukuka aykırı olması gerektiği açıkça belirtilmiş olmakla birlikte, TBK m. 37 ve m. 38'de hukuka aykırılık şartına yer verilmemiştir. Ancak öğretide, korkutulanın sözleşmeyle bağlı olmaması için korkutmanın hukuka aykırı olması gerektiği kabul edilmektedir ${ }^{16}$. Korkutmanın haklı bir sebebe dayanması halinde, korkutmanın varlığından bahsedilemez ${ }^{17}$.

Kanunkoyucu, korkutmanın şartlarını düzenleyen TBK m. 38'de ikili bir ayrıma gitmiştir. TBK m. 38/f.1'de tehdidin ne zaman korkutma sayılacağına ilişkin genel şartlara yer verilmiş; TBK m. 38/f.2'de ise bir hak ya da kanundan doğan yetkinin kullanılacă̆ bildirilerek yapılan kokutmanın özel şartları düzenlenmiştir ${ }^{18}$. Kokutmanın hukuka aykırıllğı konusu kanunun bu sistematiğine uygun olarak önce TBK m. 38/f.1 hükmü, sonra da onun özel bir görünümü olan TBK m. 38/f.2 hükmü ele alınarak incelenmiştir ${ }^{19}$.

\section{A. Bir Hakka ya da Kanundan Doğan Yetkinin Kullanılmasına Dayanmayan Korkutmanın Hukuka Aykırı Olması (TBK m. 38/f.I)}

Bir kişiyi belirli bir yönde irade açıklamasında bulunmaya sevketmek için mevcut bir hakkın veya yetkinin kullanılması durumunda yapılan irade açıklaması hüküm ve sonuç doğurur. Kişinin bir takım sebeplerle irade açıklamasına sevkedilmiş olması, açıklamanın tehdit sonucu yapıldığını göstermez. Burada önemli olan husus, irade açıklamasında bulunmaya yönelik karar verme özgürlüğünün hukuka aykırı biçimde sınırlandırılmış olup olmadığıdır. Bu sebeple, tehdidin hukuka aykırılığından anlaşılması gereken kişinin karar verme özgürlügüne müdahale etmenin hukuka aykırı olmasıdır ${ }^{20}$.

15 Bucher, s. 225; Demirbaş, s. 5; Antalya, s. 406, N. 1765.

16 Etter, s. 66; von Tuhr/Peter, s. 326; Gauch/Schluep/Schmid, s. 201, N. 880; Schmidlin, Art. 29/30 N. 35; Präjudizienbuch OR/Bernhard, Gauch, Peter/Aepli, Viktor/Stöckli, Hubert (Hrsg), Präjudizienbuch OR Rechtsprechung des Bundesgerichts (1875-2015), 9. Auflage, Zurich 2016, Art. 29, N. 2; Tekinay/Akman/Burcuoğlu/Altop, s. 451; Kocayusufpaşaoğlu/Hatemi/Serozan/Arpacı, s. 477, N. 9; Eren, s. 456, N. 1246; Kılıçoğlu, s. 284; İstanbul Şerhi/ Kurşat, m. 38, N. 9; Esener/Gündoğdu, s. 168; Günergök, Özcan/Kayıhan, Şaban, Borçlar Hukuku Dersleri (Genel Hükümler), İstanbul 2020, s. 143.

17 Gauch/Schluep/Schmid, s. 201, N. 880; Schmidlin, Art. 29/30, N. 33; Etter, s. 66; Schwenzer, s. 299, N. 38.20; Oğuzman/ Öz, s. 121, N. 370; Köroğlu, s. 133.

18 "Borçlar Kanununun 30. maddesinin 2. fikrası hükmünce yasaya uygun bir yetkinin kullanılacağı tehdidi altında yapılmış bir tasarrufun iptali için ayn maddenin birinci fikrasında gösterilen genel unsurların da olayda gerçekleşmesi gerekir.", Yarg. 4. HD, E. 1967/2642, K. 1967/3792, T. 2.5.1967, Kazancı İçtihat Bilgi Bankası.

19 Etter, s. 77; Demirbaş, s. 71; Köroğlu, s. 134. TBK m. 38/f.1 hükmü ana kural, TBK m. 38/f.2 hükmü ise yan kural niteliğindedir., Schmidlin, Art. 29/30, N. 34. 
Sözleşmenin kurulmasından önce taraflar arasında bir müzakere süreci vardır. Bu müzakere sürecinin başarıya ulaşması halinde sözleşme kurulur. İşte bu süreçte taraflar arasında edimden bağımsız bir borç ilişkisi doğar. Taraflar birbirlerini korumak ve zarar verebilecek davranışlardan kaçınmak yükümlülüğü altındadırlar ${ }^{21}$. Bu ilişkinin kaynağı TMK m.2’de yer alan dürüstlük kuralıdır ${ }^{22}$. Müzakere sürecinde gerçekleşen tehdit fiilinde, tehdit eden diğer tarafın menfaatlerini koruma yükümlülügüünü ihlal etmektedir. Sözleşme tarafının ya da üçüncü kişinin yukarıda belirtilen unsurları taşıyan tehdit fiili, karşı tarafın sözleşmenin kurulmasına ilişkin karar verme özgürlüğüne etki ederek, onun iradesini baskı altına almakta böylece ona zarar vermektedir. Bu şekilde koruma yükümlülügünü ihlal eden ve diğer tarafa zarar veren tehdit eden culpa in contrehando sorumluluğu kapsaminda sorumlu olur ${ }^{23}$.

Korkutma, TBK m. 37 ve 38'de sözleşmenin kurulması esas alınarak düzenlenmiş olsa da, sözleşmenin kurulmasından sonra da korkutma söz konusu olabilir. Örneğin, kurulmuş olan sözleşmedeki şartlar değiştirilmediği takdirde ifanın yapılmayacă̆ı; haklı bir sebep olmaksızın ek ödeme yapılmadığı takdirde sözleşme konusu şeyin teslim edilmeyeceği şeklindeki fiiller de hukuka aykırıdır ${ }^{24}$. Bu gibi fiillerle karşılaşan alacaklının borçlunun borca aykırı davranışı sebebiyle borca aykırılık sorumluluğu çerçevesinde onun sorumluluğuna gidebilmesi mümkündür. Ancak, bazı durumların varlığı halinde borcun ifa edilmemesi alacaklının büyük bir zarara uğramasına neden olabilir ${ }^{25}$. Bu gibi durumlarda alacaklının menfaatinin korunması gerekmekte olup, borca aykırı davranan borçlu alacaklıyı ekonomik olarak zor duruma sokmakla tehdit ederek, onun yeni bir sözleşme yapmak konusunda serbestçe karar verememesine neden olmaktadır ${ }^{26}$.

Tehdit bir haksız fiilinin unsurlarını taşıyabileceği gibi, kanunda öngörülen suç tiplerinden birine uygun bir fiil de olabilir ${ }^{27}$. Kişinin kendisinin ya da yakınlarının öldürüleceği, yaralanacağı, malvarlığına

21 Serozan, Rona, "Culpa in Contrahendo", "Akdin Müsbet İhlali” ve "Üçüncü Kişiyi Koruyucu Etkili Sözleşme” Kurumlarının Ortak Temeli: Edim Yükümlerinden Bağımsız Borç İlişkisi, İÜMHAD, C. 2, S. 3, 1968, s. 117 vd.; Ergüne, Mehmet Serkan, Olumsuz Zarar, İstanbul 2008, s. 112 vd.; Gezder, Ümit, Türk/İsviçre Hukukunda Culpa in Contrahendo Sorumluluğu, İstanbul 2009, s. 155-156.

22 Serozan, s. 117; Ergüne, s. 115.

23 Demirbaş, s. 68; Nomer, s. 105, N. 68.2.

24 von Tuhr/Peter, s. 326; Gauch/Schluep/Schmid, s. 201, N. 880; Bucher, s. 226; Schwenzer, s. 299, N 38.20; Demirbaş, s. 69; Köroğlu, s. 48; Eren, s. 456, N. 1246. Yargıtay vermiş olduğu bir kararda borç olarak verilen 9.000 TL’nin yarısından vazgeçilmediği takdirde ödemede bulunulmayacağı tehdidinin kokutma sayılmayacağını belirtmiştir., Yarg. 4. HD, E. 1967/8417, K. 1968/5402, T. 25.06.1968, Kazancı İçtihat Bilgi Bankası. Bu kararın isabetsiz bir karar olduğuna ilişkin bkz. Köroğlu, s. 136; Demirbaş, s. 69, dn. 213.

25 Yabancı bir ülkeden mal satın alan ve malların son teslimatının yapılmasından önce borçlu tarafından satım bedelinin artırılması, aksi takdirde teslimatın yapılmayacağı tehdidi ile karşılan alacaklının, söz konusu ücret artırımını reddederek, teslimatın gerçekleşmemesi halinde yabancı bir ülkede tazminat davası yürütmenin zorluğundan çekinmesi sebebiyle ek ücret ödeme taahhüdünde bulunması ve teslimatın yapılmasından sonra bu beyanını iptal etmesi kokutma nedeniyle haklı görülmelidir., BGE 32 II 641.

26 Schmidlin, Art. 29/30, N. 36. Alacaklı da sözleşmeden doğan borcunu ifa etmeyeceğini bildiren borçluyu alacağını elde etmek amacıyla tehdit edebilir. Bu ihtimalde, alacağını hukuk dışı yollarla elde eden alacaklının korunmaması gerektiği, borç konusu şeyi tehdit edilmesi sebebiyle vermek zorunda kalan borçlunun korkutma sebebiyle vermiş olduğu şeyin iadesini talep edebilmelidir., Akyol, s. 324-325; Demirbaş, s. 70.

27 von Tuhr/Peter, s. 326; Gauch/Schluep/Schmid, s. 201, N. 880; Basler Komm. OR I/Schwenzer, Art. 29, N. 7; Bucher, s. 226; Tekinay/Akman/Burcuoğlu/Altop, s. 451; Kocayusufpaşaoğlu/Hatemi/Serozan/Arpacı, s. 477, N. 9; Akyol, s. 
zarar verileceği tehdidi hem haksız fiile hem de suça ilişkin unsurları ihtiva etmekte olup, hukuka aykırı olduğu hususunda tereddüt bulunmamaktadır. Ancak, sözleşmenin yapılmasına neden olan tehdit, zorunluluk hali, meşru müdafaa gibi hukuka uygunluk sebeplerinin varlığı halinde hukuka aykırı olmayacaktır. Korkutmanın varlığının kabulü açısından tehdidin mutlaka bir haksız fiil veya suç teşkil etmesi zorunlu değildir. Korkutmanın hukuka aykırılı̆̆ açısından tehdit edenin bu tehdidin korkutma teşkil ettiğini bilmesi yeterlidir. Tehdit edilenin fiilin hukuka aykırı bir nitelik taşıdığını bilmesi aranmaz 28 .

\section{B. Bir Hakkın veya Kanundan Doğan Yetkinin Kullanılacağı Korkutmasının Hukuka Aykırı Olması} (TBK m. 38/f.2)

Bir kişi, bir hakkın veya kanundan doğan yetkinin kullanılacağı bildirimi üzerine sözleşme yapmak zorunda kalmış ise kural olarak bu sözleşme geçerli bir sözleşmedir ve bunun bağlayıcı olmadığı ileri sürülemez ${ }^{29}$. Örneğin, alacağını elde etmek isteyen alacaklının borç ifa edilmediği takdirde icra takibine girişeceği, dava açacağı, sözleşmeyi sona erdireceği beyanı hukuka aykırı olmayıp, sadece bir hak ya da kanundan doğan yetkinin kullanılacağının bildirilmesidir. Burada haklı bir sebebe (alacağını elde etmek) dayanan alacaklı, kanunun çizdiği sınırlar içinde borçluyu ifada bulunması için zorlamaktadır. Bir hakkın veya kanundan doğan yetkinin kanunun öngördüğü kapsam ve yöntemle kullanılması durumunda hukuka aykırllık söz konusu olmaz. Anayasa m. 36'da hak arama özgürlügü güvence altına alınmıştır. Bu maddeye göre, herkes, meşru vasita ve yollardan faydalanmak suretiyle yargı mercileri önünde davacı veya davalı olarak iddia ve savunma ile adil yargılanma hakkına sahiptir. TBK m.38/f.2'de bir hak ya da kanundan doğan yetki bir sözleşmenin yapılmasında tehdit aracı olarak kullanılmaktadır ${ }^{30}$.

Bir hak ya da kanundan doğan yetkinin kullanılacağı tehdidiyle karşılan tarafın bu tehdit sebebiyle zor durumda kalması neticesinde sözleşmeyi yapmak zorunda kalması durumunda, bu sözleşme tehdit eden için aşırı bir menfaat sağlıyorsa bu tehdit hukuka aykırı olur. Bu durumda hak ya da kanundan doğan yetki, hukuk düzeninin korumadığı menfaatlerin elde edilmesi amacıyla kullanılmaktadır ${ }^{31}$.

314; Özkaya, s. 394; Demirbaş, s. 67.

28 Schmidlin, Art. 29/30, N. 38; Yavuz, s. 197; Köroğlu, s. 135.

29 Etter, s. 73; von Tuhr/Peter, s. 327; Schmidlin, Art. 29/30, N. 42; Bucher, s. 226; Basler Komm. OR I/Schwenzer, Art. 30, N. 8; Schwenzer, s. 299, N. 38.21; Eren, s. 456, N. 1246; Kılıçoğlu, s. 284; Antalya, s. 409, N. 1756; Nomer, s. 104, N. 67.1; Esener/Gündoğdu, s. 168; Günergök/Kayıhan, s. 143; Demirbaş, s. 70-71; Özkaya, s. 424; “...Öte yandan, kural olarak yasal bir hakkın kullamılacağın bildirmek dava açılacağı, icra takibi yapılacağı, iflasın isteneceği tehditlerini ileri sürmek, ya da yasal bir hakkı kullanmak ikrah sayılamaz.", Yarg. 1. HD, E. 2018/2470, K. 2018/13056, T. 3.10.2018, Kazancı İçtihat Bilgi Bankası.

30 Kılıçoğlu, s. 286; "...tacirlerin, yargıya ihbar ve şikayet edileceği tehdidiyle sözleşmeye razı edildiği durumlarda ikrah söz konusu değildir. İhbar ve şikayet, gerçeği yansittyorsa anayasal hakkın kullanılması olur; değilse onu yapan sonuçlarına katlanır., Yarg. 19. HD, E. 2002/2827, K. 2002/7580, T. 29.11.2002, Kazancı İçtihat Bilgi Bankası.

31 Saymen/Elbir, s. 277; Köroğlu, s. 138. 


\section{Hak ya da Kanundan Doğan Yetkinin Kullanılacağının Bildirilmesi}

TBK m. 38/f.2’ye göre, kokutmanın hukuka aykırılığından söz edilebilmesi için öncelikle bir hakkın veya kanundan doğan yetkinin bulunması gerekir ${ }^{32}$. Sözleşmeden doğan haklar ile Türk Borçlar Kanunundan ve mevzuattan kaynaklanan hak ve yetkiler bu kapsamda yer alır ${ }^{33}$. Hak ya da kanundan doğan yetki, bunların kullanılacağı tehdidinde bulunulduğu an itibariyle mevcut olmasa dahi, yakın sayılabilecek bir zaman diliminde doğacak bir hakkın veya kanundan doğan yetkinin kullanımı tehditleri de korkutma sayılabilir ${ }^{34}$.

Bir hak ya da kanundan doğan yetki bulunmamasına rağmen bu hak ya da yetki varmış gibi bildirim yapılması durumunda tehdit edilenin hak ya da kanundan doğan yetkinin bulunmadığını bildiği ya da somut durumun şartları çerçevesinde bilebilecek durumda olduğu söylenebiliyorsa kokutmanın hukuka aykırılığından bahsedilemez ${ }^{35}$. Tehdit edilen, gerçekte bulunmayan bir hakkın veya kanundan doğan yetkinin bulunduğuna iyiniyetli olarak inanmış ise şartları varsa TBK m. 38/f.1 hükmüne dayanarak hukuka aykırılık iddiasında bulunabilir ${ }^{36}$.

Bir hakkın veya kanundan doğan yetkinin kullanılacağı tehdidinin bu tehdit altında sözleşmeyi yapan kişinin kendisine yöneltilmiş olmalıdır. Başka bir kişiye yapılan bu şekildeki bir tehdit sebebiyle sözleşme yapılmak zorunda kalınmış ise somut olayın şartları çerçevesinde sözleşme yapanın yakınlarına yönelik bir tehdit sebebiyle (TBK m. 38/f.1) korkutmanın gerçekleştiği kabul edilebilir ${ }^{37}$.

Tehdit edilen kişi gerçek kişi olabileceği gibi bir tüzel kişi de olabilir. Tüzel kişi iradesini organları aracılığıyla açıkladığından tehdit tüzel kişinin temsile yetkili organında yer alan gerçek kişi ya da

32 Schmidlin, Art. 29/30, N. 47; Kılıçoğlu, s. 284; Özkaya, s. 425; Demirbaş, s. 71; "Bundan başka ( bir hakkın veya kanuni salahiyetin ) kullanılacağı da ileri sürülmüş olmak gerekir. Bu durumda hak niteliğinde olmayan bir şeyin istenilmesi veya kanuna aykırı bir işlemin yapılacağının söylenmesi, bu hükme uygun bir tehdidin ve ikrahın var sayılmasını gerektirmez. Davacı, Hazirandan Kasıma kadar belediyenin kendisine kiraladığı gazinoyu boşaltma yükümlülüğünü kabul etmedikçe işletme ruhsatiyesi verilmeyeceği bildirildiğinden, bu tehdit altında verilmiş 16.7.1963 günlü yükümlülük belgesinin geçersiz sayılmasına karar verilmesini istemiştir. Oysa ki belediyenin ileri sürdüğ̈̈ bildirilen ruhsatname vermeme durumu, belediye için ne bir hak ne de yasaya uygun yetkidir. Bir gazinonun belediye yönetmelikleri hükümlerine uygun durumda bulunması halinde, başvurma üzerine, belediye ruhsatname vermeğe mecburdur. Bu durumda olan bir gazino için, ruhsatname vermeme keyfiyeti, belediyenin keyfi bir davranışı olması bakımından buna karşı her zaman iptal ve tazminat davası açılabilir. O halde de yasanın geçersizlik için aradığı hak veya kanuni salahiyetin kullanılması unsurları olayda gerçekleşmiş sayılmaz. Bu yolla belediyenin olumsuz davranışı giderilebileceğine göre, mal varlığ için derhal gerçekleşecek bir tehlikeden ve ağırliğından söz dilemez. İptal için yasanın aradığı şartların gerçekleştiği düşünülemeyeceğinden davanın reddedilmemiş bulunması bozmayı gerektirir.", Yarg. 4. HD, E. 1967/2642, K. 1967/3792, T. 2.5.1967, Kazancı İçtihat Bilgi Bankası.

33 Köroğlu, s. 140.

34 Demirbaş, s. 71, dn. 219.

35 Etter, s. 77; Demirbaş, s. 71; Köroğlu, s. 140.

36 Etter, s. 78-79; Schmidlin, Art. 29/30, N. 47; Demirbaş, s. 71-72; Köroğlu, s. 141.

37 Demirbaş, s. 71, dn. 219; “Davacının dava dilekçesinde dayandığı olayları nitelemek ve bu tavsife uygun yasa maddelerini tespit edip uygulamak HUMK.nun 76. maddesi gereğince hakimin görevi gereğidir. Davacı dava dilekçesinde damadı Ersin'in borcundan dolayı davalı alacaklının icra memuru ile birlikte, borçlu Ersin'le birlikte oturduğu eve hacze geldiklerini, kızına çeyiz olarak verdiği eşyaların haczedileceği sırada Ersin'in borcunu kabul ederek 100.000 lira para ile dava konusu iki çeki davalıya bu müzayaka durumundan dolayı verdiğini ileri sürmüştür. Böylece, BK.nun 30/2. maddesine dayanmaktadır. Burada, borçlu davacı olmadiğı gibi haczedilen mallar da kendisine ait bulunmamaktadır. Bu itibarla bir hakkın veya kanuni selahiyetin kullanılacağı tehdidi ile müzayakaya düçar olduğu kabul edilemez. Bu nedenle olaya uygun düşmeyen gerekçe ile hüküm tesisi bozmayı gerektirir." Yarg. 13. HD, E. 1988/4352, K. 1998/5649, T. 24.11.1988, Legalbank. 
kişilerin iradesine etki yapmaktadır ${ }^{38}$. Temsile yetkili organ tek kişiden oluşuyor ise bu kişinin tehdide maruz kalması, tüzel kişinin korkutulması anlamına gelir. Organın birden fazla kişiden oluşması durumunda ise sözleşmenin yapılıp yapılmayacağına ilişkin karar verilirken karar çoğunluğunun sağlanmasında tehdit edilen üyenin/üyelerin etkisi bulunup bulunmadığı belirlenmelidir. Tehdit edilen üye/üyelerin katılımıyla karar alınmış ve sözleşme yapılmış ise, tüzel kişi korkutma sebebiyle sözleşmeyle bağlı olmadığını ileri sürebilir. Temsile yetkili olmayan organa yönelen tehdit ise korkutma teşkil etmez ${ }^{39}$.

Hak ya da kanundan doğan yetkinin kullanılması birçok sebepten kaynaklanabilir. Alacaklının alacağını tahsil etmeye yönelik ifa talebi, dava açması, icra takibine başlaması, takip sürecinde haciz ya da satış talebi tehdit konusu olabilir ${ }^{40}$. Alacak hakkı dışında kalan diğer kişisel hakların özellikle yenilik doğuran haklar ile def'i haklarının kullanılacağı da bildirilebilir ${ }^{41}$.

Aile ve miras hukukundan doğan hakların kullanılacağı tehdidiyle de bir kişinin sözleşme yapması sağlanabilir ${ }^{42}$. Ayrıca, suç işleyen bir kişinin bu suçun ihbar veya şikâyet edileceği tehdidi ile sözleşme yapmaya zorlanması da söz konusu olabilir ${ }^{43}$.

38 Gauch/Schluep/Schmid, s. 200, N. 876; Schmidlin, Art. 29/30, N, 28; Basler Komm. OR I/Schwenzer, Art. 30, N. 4-5; Tekinay/Akman/Burcuoğlu/Altop, s. 449; Antalya, s. 406, N. 1764; İstanbul Şerhi/Kurşat, m. 38, N. 6, dn. 72; Kocayusufpaşaoğlu/Hatemi/Serozan/Arpacı, s. 475, N. 6; Oğuzman/Öz, s. 120, N. 366, dn. 361; Demirbaş, s. 47; Özkaya, s. 393. Tüzel kişiyi temsile yetkili organlar her bir tüzel kişi için ilgili kanunlarda düzenlenmiştir. Bkz. TMK m. 84, 109, TTK m. 223, 318, 365, 623, Kooperatifler Kanunu m. 56.

39 Köroğlu, s. 96-97.

40 von Tuhr/Peter, s. 327; Etter, s. 80; Bucher, s. 226; Tekinay/Akman/Burcuoğlu/Altop, s. 451; Kocayusufpaşaoğlu/ Hatemi/Serozan/Arpacı, s. 477, N. 9; Akyol, s. 316.

41 Etter, s. 80; Tekinay/Akman/Burcuoğlu/Altop, s. 451; Demirbaş, s. 142. Tehdit edenin sözleşmeyi feshedeceğini, önalım hakkını kullanacağını, kendisine yapılan bir başka teklifi kabul edeceğini bildirmesi örnek verilebilir., Köroğlu, s. 142 .

42 Etter, s. 80; Köroğlu, s. 142. Eşlerden biri istediği bedel ödenmedikçe boşanmaya razı olmayacağını diğer eşe mirasbırakan belirli bir kişiyle evlenmediği takdirde mirasından mahrum bırakacağını mirasçısına bildirdiğinde muhatabını zor durumda birakmaktadır., Demirbaş, s. 73.

43 Kural olarak, kanunda suç olarak düzenlenmiş olan bir fiili işleyen kişiye işlediği suçun yetkili makamlara ihbar ya da şikayet edileceğini bildirmek hukuka aykırı bir nitelik taşımaz., Etter, s. 81; Schmidlin, Art. 29/30, N. 44; Demirbaş, s. 73; bkz. BGE 125 III 353. Yapılması istenen sözleşme ile işlenen suç arasında objektif bir bağlantı varsa yani sözleşme işlenen suçun sonuçları ile ilgiliyse ve suç ihbarında veya şikayetinde bulunulacağı tehdidi suç işleyenin zor durumda kalması sebebiyle aşırı bir menfaat elde edilmesini sağlıyor ise, bu tehdit hukuka aykırıdır. Aşırı menfaat sağlanması söz konusu değilse tehdidin hukuka aykırılığından bahsedilemez., von Tuhr/Peter, s. 328; Basler Koom. OR I/Schwenzer, Art. 30, N. 9; Präjudizienbuch OR/Bernhard, Art. 30, N. 4; Kocayusufpaşaoğlu/Hatemi/Serozan/Arpacı, s. 477, N. 10; Antalya, s. 410, N. 1788; Köroğlu, s. 143; BGE 125 III 353; bkz. Tercier/Pichonnaz/Develioğlu, s. 287, N. 896. Örneğin, A’nın aracına 5.000 TL zarar veren B’ye karşı 10.000 TL ödemediği takdirde bu suçun ihbar veya şikâyet edileceği tehdidinde bulunması durumunda, A, B’nin zor durumunda kalmasından aşırı menfaat elde ettiğinden, bu tehdit hukuka aykırı olur. A’nın 5.000 TL talep etmesi durumunda ise ödemeyi yapan B, tehdidin hukuka aykırı olduğunu ileri süremez. Yapılması istenen sözleşme ile işlenen suç arasında herhangi bir bağlantı yoksa, örneğin aracı hasara uğrayan A, hasar tutarı ödenmediği takdirde B'nin daha önce işlemiş olduğu suç teşkil eden bir fiili ihbar veya şikayet edeceğini bildirmişse şartları varsa TBK m. 38/f.1 uygulanır., Basler Komm. OR I/Schwenzer, Art. 30, N. 9; Kocayusufpaşaoğlu/Hatemi/Serozan/Arpacı, s. 478, N. 10; Antalya, s. 410, N. 1788; Köroğlu, s. 144; Demirbaş, s. 76; "Bu cümleden olarak bir hakkın veya kanuni yetkinin kullanılması sözkonusu olmadıkça tehdit hukuka aykırı olduğu gibi, bir hakkın veya kanuni yetkinin kullanılacağı tehdidinin tehdit olunan için yarattığı güç durumdan aşırı menfaat elde etmek üzere yararlanılmışsa yapılan tehdit yine hukuka aykırıdır. ( BK.Mad.30/II ) Örneğin,... bir ceza davası açma tehdidi ile aşırı menfaat sağlayacak bir sözleşmenin yapılması böyledir.", Yarg. 3. HD, E. 2000/8427, K. 2000/9776, T. 12.10.2000, Kazancı İçtihat Bilgi Bankası. 
Tehdit edenin serbest tasarrufunda olan (tehdit edilenin kabulüne veya iznine ihtiyaç duyulmayan) işlemleri aleyhe kullanacağını bildirerek tehdit edilenden aşırı bir menfaat elde etmesi de mümkündür ${ }^{44}$.

\section{Korkutulanın Zor Durumda Kalmasından Aşırı Bir Menfaat Sağlanması}

\section{a. Genel Olarak}

Bir hakkın veya kanundan doğan yetkinin kullanılacağı bildirimi tehdit edilenin zor durumda kalmasından dolayı bildirimde bulunana aşırı bir menfaat sağlamış olmalıdır. Bu şart açısından "zor durumda kalma" ve "zor durumda kalmadan kaynaklı aşırı menfaat sağlama" unsurları birlikte gerçekleşmedikçe korkutmanın varlığından bahsedilemez.

Öğretide bir görüşe göre ${ }^{45}$, tehdit edilenin zor durumda kalması unsurunun ayrıca belirtilmesine ihtiyaç yoktur. Tehdit edilenin zor durumda kalması ile kastedilen, tehdit sonrası tehdit edilenin içerisine düştüğü durumdur ve bu tehdidin genel şartlarını düzenleyen TBK m. 38/f.1 hükmünde de aranmaktadır. Bu sebeple, TBK m. 38/f.2 hükmünün uygulanabilmesi açısından önemli olan unsur tehdit edenin aşırı bir menfaat sağlamasıdır.

Tehdit edilen zor durumda kalsa da bir hakkın veya kanundan doğan yetkinin kullanılması tehdit eden açısından aşırı bir menfaat sağlamıyor ise ortada hukuka aykırı bir durum bulunmayacağından dolayı kokutma söz konusu olmaz ${ }^{46}$.

44 Yargıtay vermiş olduğu bir kararda bir avukatın tutuklu müvekkilinin bu durumundan faydalanarak davaya devam etmeyeceği ve bu durumda işlerin çok daha kötü olacağı tehdidiyle müvekkilini kendisine ödünç para verdiği yönünde irade açıklamasında bulunmaya sevketmesinin korkutma olduğuna hükmetmiştir., Yarg. 4. HD, E. 1969/148, K. 1969/1698, T. 4.11.1969, Kazancı İçtihat Bilgi Bankası. Arabasını kendisine vermediği takdirde boşanma davası açacağını bildiren kocanın bu tehdidi karşııında arabanın devrini gerçekleştiren eş açısından sözleşme bağlayıcı değildir., Yarg. 2. HD, E. 1997/7595, K. 1997/8078, T. 9.7.1997, Kazancı İçtihat Bilgi Bankası. Kiralayanın kira sözleşmesini fesih hakkını kullanacağını bildirerek, kiracının aşırı bedel ile sözleşmeyi yenilemesini sağlamasında da kiralayan fesih hakkını bir tehdit olarak kullanmaktadır., YHGK, E. 2004/3-192, K. 2004/174, T. 31.3.2004, Kazancı İçtihat Bilgi Bankası.

45 Tunçomağ, Kenan, Türk Borçlar Hukuku, I. Cilt, Genel Hükümler, Altıncı Bası, İstanbul 1976, s. 365-366.

46 Köroğlu, s. 145; Antalya, s. 409, N. 1787; Esener/Gündoğdu, s. 168-169; Özkaya, s. 424; “íkrah olunan taraf, hal ve mevkiine nazaran kendisinin yahut yakın akrabasından birinin hayat veya şahıs veya namus yahut malları ağır ve derhal vukubulacak bir tehlikeye maruz olduğuna kanaat getirdiği takdirde ikrah, muteber addolunur. Bir hakkın veya kanuni salâhiyetin isteneceği ve kullanılacağı tehdidi ile müzayakaya düçar olan kimsenin yaptığı akit, tehdit eden için fahiş menfaatler temin etmiyorsa; bu tehdit, ikrahı muteber addolunmaz. Fakat fahiş menfaatler istihsali için tehdit olunan tarafin müzayaka halinde bulunmasından istifade olunmuş olursa bu korku nazara alıntr.", Yarg. 11. HD, E. 2005/13977, K. 2007/1287, T. 5.2.2007, Kazancı İçtihat Bilgi Bankası; "İkrahın koşulları B.K.nun 30.maddesinde belirtilmiş olup, aynı maddenin 2.fikrasında bir hakkın veya kanuni yetkinin isteneceği veya kullanılacağı tehdidi ile müzayakaya dûçar olan kimsenin yaptığı akdin, tehdit eden için fahiş menfaatler temin etmemesi halinde tehdidin ikrah teşkil etmeyeceği hükmü getirilmişșir. Olayda davacı şirket ve ortakları ile yetkililerinin hayat, namus, mal ve hürriyetine yönelik bir tehdidin varllğı ileri sürülüp kanıtlanmış değildir. Davalı idarenin bağl bulunduğu bakanlğın başında bulunan bakanın, keşif artışı ile ilgili işleri 2001 yll fiyatları ile yapmayı kabul ettiğine dair taahhütname vermemesi halinde keșif artışını imzalamayacağı, sözleşmeyi feshedeceği ve hakediş ödemesini geciktireceğine dair beyanı, taahhütname tarihi itibariyle keşif artışıın iş bedelinin \%30'unu aşması nedeniyle keşif artışııı imzalamama ve sözleşmeyi fesih yetkisi bulunduğundan kanuni yetkinin kullanılacağın bildirme niteliğindedir. Dava konusu işin \%30 keşif artışı dışında kalması nedeniyle bu işin yapılması ayrı bir sözleme konusu olup davalı idarenin yeniden ihale yaparak işi aynı veya daha düşük bedelle başka bir yükleniciye vermesi ihtimali gözden uzak tutulamayacağından idarenin fahiş menfaat temin ettiğinden söz etmek mümkün değildir. Bunun yanında idarenin ne șekilde fahiş menfaat temin ettiği 
Öğretide TBK m. 28'de düzenlenen aşırı yararlanmanın şartlarından olan zor durumda kalma ve yararlanma şartlarının TBK m. 38/f.2 için de aynen aranması gerektiği kabul edilmektedir ${ }^{47}$.

Bununla birlikte her iki düzenleme arasında farklar da bulunmaktadır. TBK m. 38/f.2'de belirtilen zor durumda kalma, tehdit edenin bir hak ya da kanundan doğan yetkinin kullanılacağı bildiriminden sonra ortaya çıkmaktadı4 ${ }^{48}$. TBK m. 28 'de düzenlenen aşırı yararlanma durumunda ise kişi sözleşme yapılmadan önce olumsuz bir durum içinde bulunmakta, bu durumun elverişsiz koşullarından kurtulmak amacıyla sözleşme yapmaktadır. Burada tehdit kastıyla hareket edilerek, bir kişinin sözleşme kurmaya sevkedilmesi söz konusu değildir ${ }^{49}$. Ayrıca, TBK m. 38/f.2'de belirtilen zorda kalma durumu, sözleşmenin tarafı dışında bir üçüncü kişinin tehdidiyle de ortaya çıkabileceğinden TBK m. 28 hükmünden farklılaşmaktadır ${ }^{50}$.

\section{b. Korkutulanın Zor Durumda Kalması}

TBK m. 38/f.2'ye göre, korkutmanın varlığının kabul edilebilmesi için, bir hakkın veya kanundan doğan yetkinin kullanılacağı tehdidi karşı tarafın zor durumda kalmasına neden olmalıdır.

Zor durumda kalmadan anlaşılması gereken tehdit edilenin sözleşmeyi kurarken maddi ya da manevi açıdan şiddetli bir sıkıntı ve çaresizlik hissetmesidir ${ }^{51}$. Zor durumda kalma genellikle mali ya da ekonomik bir sıkıntı içine girme şeklinde karşımıza çıkmaktadır ${ }^{52}$.

Bir hak ya da kanundan doğan yetkinin kullanılacağı tehdidi ile karşı karşıya kalan kişinin bu tehditten önceki durumu bu tehdit ile sarsılmakta, kendisinin tehdit edenin aşırı bir menfaat sağlayacağı bir sözleşme yapmak ya da bu tehdidin olumsuz sonuçlarına maruz kalma dışında başka bir seçeneği bulunmamaktadır. Tehdit edilen kişi, tehdit fiilinin gerçekleşmesi sonucunda karşılaşacağı olumsuz sonuçların sözleşme kurmaya göre daha ağır ve tehlikeli olacağını düşünerek, sözleşmeye yapmayı tercih etmektedir ${ }^{53}$. Borcu sebebiyle hakkında icra takibine başlanacağı beyanıyla karşılaşan borçlunun, bu takip sebebiyle çok daha fazla zarara uğrayacağı düşüncesiyle taşınmazını değerinden düşük bir bedelle satmayı kabul etmesi bu duruma örnek verilebilir.

de somut delillerle kanıtlanamamıştır. Kaldı ki davacı müzayaka halinde olması nedeniyle taahhütnameyi verdiğini ispat edemediği gibi keşif artışları dahil tüm iş bedeli dikkate alındığında müzayaka halinde bulunduğınun kabulü de mümkün değildir.", Yarg. 15. HD, E. 2004/4318, K. 2005/2091, T. 7.4.2005, Kazancı İçtihat Bilgi Bankası.

47 Etter, s. 84, von Tuhr/Peter, s. 327, dn. 47; Präjudizienbuch OR/Bernhard, Art. 30, N. 4; Antalya, s. 409, N. 1787; Kocayusufpaşaoğlu/Hatemi/Serozan/Arpacı, s. 477, dn. 18; Köroğlu, s. 146; Demirbaş, s. 77, dn. 242.

48 Etter, s. 79 vd..

49 Demirbaş, s. 77, dn. 242.

50 Belser, Eva Maria, Freiheit und Gerechtigkeit im Vertragsrecht, Freiburg (Schweiz) 2000, s. 341, Demirbaş, s. 77, dn. 242'den naklen.

51 Berner Komm. OR/Kramer, Meier-Hayoz Artur (Hrsg.), Berner Kommentar, Band VI, 1. Abteilung Allgemeine Bestimmungen, 2. Teilband, Unterteilband 1a, Inhalt des Vertrages, Kommentar zu Art. 19-20 OR, Bern 1991, Art. 21, N. 36; Antalya, s. 419, N. 1840; Kocayusufpaşaoğlu/Hatemi/Serozan/Arpacı, s. 489, N. 16; Köroğlu, s. 147; Kılıçoğlu, s. 291-292; Oğuzman/Öz, s. 143, N. 431.

52 Antalya, s. 419, N. 1840; Kocayusufpaşaoğlu/Hatemi/Serozan/Arpacı, s. 489, N. 16.

53 Oser/Schönenberger, Art. 30, N. 13; Demirbaş, s. 77; Köroğlu, s. 148. 
Zor durumda kalma halinin süreklilik göstermesi zorunlu değildir. Önemli olan sözleşmenin kurulması anında tehdit edilenin zor durumda kalmasıdır ${ }^{54}$.

Örneğin, A şirketi ile S şirketi arasında akdedilen bir satış sözleşmesinde A’ya teslim ettiği ürünlerin ayıplı olduğunu kabul eden S’nin, bu ürünlerin ve A’nın sipariş aşamasında yaptığı ön ödeme ile satış tutarının kalan kısmı için teminat olarak verdiği teminat mektubunun iadesinin sözleşme gereği kendisinin ibra edilmesi şartıyla mümkün olabileceğini A’ya bildirmesinin TBK m. 38/f.2 anlamında bir korkutma sayılabilmesi için bu bildirim üzerine A’nın zor durumda kalması ve S’nin aşırı menfaat sağlamış olması gerekir. Bu örnekte, ayıplı ifadan doğan zararlarını da talep eden ancak bu talebi satıcı tarafından kabul edilmeyen alıcı şirket ön ödemenin ve teminat mektubunun iadesi gerçekleşemediği takdirde mali ya da ekonomik açıdan zorda kalacağı düşüncesiyle ibra sözleşmesi yapmak zorunda kalabilir. Bu durumda, zorda kalma halinin varlığ 1 açısından alıcı şirketin mali verilerinin incelenmesi, sözleşmenin yapıldığı tarihteki şirketin kısa vadeli borç ödeme gücünün tespit edilmesi gerekir. Borç ödeme gücünün belirlenebilmesi için de likidite oranı ve nakit oranı hesaplanmalıdır ${ }^{55}$. Bu oranların düşük seviyelerde ${ }^{56}$ kalması durumunda ise şirketin kısa vadeli borçlarını ödemede güçlük çekeceği bu bağlamda zorda kalma halinin gerçekleştiği kabul edilebilir.

\section{c) Aşırı Menfaat Sağlanması}

Bir hak ya da kanundan doğan yetkinin amacına uygun kullanılması halinde hukuk düzenine aykırılıktan söz edilemez. Burada hukuka aykırılığa neden olan husus hak ya da kanundan doğan yetki kullanılarak aşırı menfaat sağlanmasıdır ${ }^{57}$. Korkutmanın varlığı açısından aşırı menfaat sağlama olgusu gerçekleşmiş olmalıdır. Bir başka anlatımla, bir hak ya da kanundan doğan yetkinin kullanılacağı tehdidine maruz kalan kişi zor durumda kalmış olabilir. Ancak, bu zor durumda kalmadan tehdit eden aşırı bir menfaat elde etmelidir ki korkutma gerçekleşmiş olsun. Tehdit eden aşırı bir menfaat sağlamamış ise karşı tarafın zor durumda kalması tek başına korkutmanın varlığının kabulü için yeterli değildir ${ }^{58}$.

54 Köroğlu, s. 148.

55 Likidite oranı, şirketin kısa vadeli borç ödeme gücünü ortaya koymak amacıyla hesaplanır. Likidite oranının temel aldığı veriler; aktifte yer alan dönen varlıklar ve pasifte yer alan kısa vadeli borçlardır. Likidite Oranı (Asit-Test Oranı) $=($ Dönen Varlıklar - Stoklar) / Kısa Vadeli Borçlar şeklinde formüle edilir. Nakit oran, ticari alacaklar tahsil edilmeksizin ve stoklar paraya çevrilmeksizin bir başka deyişle nakit girişi olmaksızın şirketin kısa vadeli borçlarını ödeme gücünü gösterir. Nakit oranın çok düşük olması, şirketin nakit sıkıntısı içerisinde olduğuna işaret etmektedir. Nakit Oran = Hazır Değerler $/$ Kısa Vadeli Borçlar şeklinde formüle edilir., Gümüş, Umut, Tolga/Şakar, Zekayi/Akkın, Gürkan/Şahin, Mustafa, "Finansal Analizde Kullanılan Oranlar ve Firma Değer İlişkisi: BİST’de İşlem Gören Çimento Firmaları Üzerine Bir Analiz”, Karadeniz Sosyal Bilimler Dergisi , C. 9, S. 16, 2017, s. 4 vd.; Yenisu, Ersin, "Finansal Tabloların Oran Analizi İle İncelenmesi: Adese Örneği”, Aksaray Üniversitesi Sosyal Bilimler Enstitüsü Dergisi, C. 3, S. 1, 2019, s. 25-26.

56 Uygulamada likidite oranının 1 ile 1,5 arasında hesaplanması normal kabul edilmekte, söz konusu oranın 1'in altında olması yetersiz likit varlık olduğu izlenimi vermektedir. Nakit oranın ise 0,20 olması normal kabul edilmektedir., Tenker, Nejat/Akdoğan, Nalan, Finansal Tablolar ve Mali Analiz Teknikleri, 13. Baskı, Ankara 2010, s. 649; Tekin, İbrahim, Finansal Analiz Teknikleri ve Finansal Analiz Üzerine Bir Uygulama, Adıyaman Üniversitesi Sosyal Bilimler Enstitüsü, Yayımlanmamış Yüksek Lisans Tezi, 2017, s. 41 vd.; Yenisu, s. 25-26.

57 Bucher, s. 226; Gauch/Schluep/Schmid, s. 201, N. 880; Basler Komm. OR I/Schwenzer, Art. 30, N. 8; Tekinay/Akman/ Burcuoğlu/Altop, s. 451; Kocayusufpaşaoğlu/Hatemi/Serozan/Arpacı, s. 477, N. 9; Hatemi/Gökyayla, s. 94.

58 von Tuhr/Peter, s. 327; Basler Komm. OR I/Schwenzer, Art. 30, N. 8; Kılıçoğlu, s. 287; Esener/Gündoğdu, s. 168-169; 
Aşırı menfaat sağlamak amacıyla bir hakkın veya kanundan doğan yetkinin kullanılacağı tehdidinin sözleşmenin karşı tarafı ya da üçüncü kişi tarafından yapılması açısından bir fark bulunmamaktadır. Ancak, üçüncü kişi tarafından yapılan tehdit sonucunda yapılan sözleşmenin bu kişi açısından aşırı menfaat sağlaması gerekir. Sözleşme üçüncü kişiye aşırı bir menfaat sağlamıyor ise TBK m. 38/f.1 kapsamında hukuka aykırılık gerçekleşmiş olur ${ }^{59}$.

Tehdit edenin aşırı bir menfaat sağlayıp sağlamadığını takdir edecek olan hâkimdir. Hâkim, hakkın veya kanundan doğan yetkinin kullanılmasıyla elde edilebilecek menfaati önemli ölçüde aşan bir menfaat sağlandığına kanaat getirmiş ise korkutma gerçekleşmiştir ${ }^{60}$. Aksi durum, hak ya da kanundan doğan yetkinin kullanılacağı tehdidinin korkutma sayılmasına engeldir ${ }^{61}$.

\footnotetext{
Özkaya, s. 426.

59 Demirbaş, s. 80.
}

60 Etter, s. 83; Bucher, s. 226; Schmidlin, Art. 29/30, N. 50; Präjudizienbuch OR/Bernhard, Art. 30, N. 4; Özkaya, s. 426; Köroğlu, s. 149-150. İşverenin işyerindeki mallara zarar veren işçiye 10.000 TL'lik bir senet imzalamadığ takdirde iş akdine son vereceğini bildirmesi durumunda işçinin verdiği zararın miktarı dikkate alınacaktır. Zarar tutarı senette belirtilen tutar kadar ise hukuka aykırılık söz konusu değildir. Ancak zarar tutarı daha az ise iş akdine son verileceği bildirimiyle zor duruma düşen işçinin bu durumundan yararlanılarak, aşırı bir menfaat elde edildiği kabul edilebilecektir., Demirbaş, s. 78-79. Tahliye davasını kazanan kiraya verenin, mevcut kiranın üç katını vermesi koşuluyla yeni bir sözleşme yaparak dairede oturmaya devam edebileceğini kiracıya bildirmesi durumunda, kiraya verenin talep ettiği yüksek kira bedelinin aynı konumdaki bir daireye göre aşırı bir farklılık gösterip göstermediği araştırılarak sonuca varılacaktır., Kılıçoğlu, s. 287-288. "Bir hakkın kullanılacağı tehdidi ile düzenlenen borç belgesi, yalnız bu tehdit yüzünden geçersiz sayılmaz. Belgenin geçersizliği için, borçlananın müzayakaya düşüp elde edilen faydanın fahiş olması gerektir. Davalının kardeşi ve kardeşinin çocuğu olan davacılardan aldığı 1673 liralık borç belgesi gerçekten çalınan eşyaya ilişkin ise, belge tehdit veya müzayaka ile elde edilse bile, iptal gerekmez. Çünkü, yalnız bu halde, faydanın fahiş olması değil, zararın giderilmesi söz konusudur. O halde, bu nitelikteki bir uyuşmazlıkda, Borçlar Kanununun 30. maddesinin son fikrası hükmünce, geçersizliğe karar verilmesi için aranan diğer iki şartın olayda var olup olmadı̆̆ı yönünün incelenmemiş olması usul ve kanuna aykırıdır.", Yarg. 4. HD, E. 1964/9295, K. 1965/6717, T. 2.12.1965, Kazancı İçtihat Bilgi Bankası.

61 "Davacıların kiralananda otururlarken ve Yasanın korunması altında bulundukları esnada verdikleri tahliye taahhütleri geçerlidir. 6570 sayılı Ka. Mad. 7/a ). Olayda davalının aldığı bu tahliye taahhüdünü tahliye konusunda bir tehdit ve baskı aracı olarak kullanmak suretiyle kira bedellerini aşırı arttırdığı veya başkaca toplu paralar aldığı ve böylece fahiş menfaat elde ettiği iddia edilmediğine göre sonraki yillarda alınan ve önceki tahliye taahhüdünü izleyen tahliye taahhütleri de geçerlidir. Çünkü Borçlar Kanunu'nun 31. maddesinin 2. fikrası gereğince bir hakkın veya kanuni yetkinin kullanılacă̆ tahdidi, fahiş menfaatler elde edilmemiş ise hukuka aykırı sayılmaz ve böyle bir ikrah işlemi geçersiz hale getirmez. Öte yandan davalı kiralayanın sadece birden çok tahliye taahhüdü alması kötü niyetli olduğunun kabulüne neden teşkil etmez. Davalının geçerli bir tahliye taahhüdüne rağmen, kira sözleşmesini tekrar tahliye taahhüdü alarak yenilemesi ve başkaca aşırı bir yarar elde etmemesi kiracının da yararına uygundur.", YHGK, E. 1990/13-352, K. 1990/447, T. 3.10.1990, Kazancı İçtihat Bilgi Bankası; "Borçlar Kanununun 30. maddesinde ikrahın şartları açıklanmıştır. Buna göre, bir hakkın veya kanuni yetkinin talep ve kullanılması tehdidi ile müzayakaya duçar olan kimsenin yaptiğı akit, tehdit eden için fahiş menfaatler temin etmiyorsa bu tehdit muteber addolunamaz. Fakat, tehdit olunan taraftan fahiş menfaatler istihsali için kendisinin hali müzayakada bulunmasından istifade olunmuş olursa, bu korkunun göz önünde tutulmasi gerekmektedir. Olayda ise, sözü geçen kollektif şirketin tehdidi altında fahiş menfaatlerin temin edilmiş olduğunu göstererek bir halin mevcudiyeti ispat edilmiş değildir. Zira, dosyadaki belgelere ve bilirkişi raporundaki açıklamalara göre; alacağın esası 80.000 liradan ibarettir. Geri kalan 20.000 liranın ise cezai şart olduğu anlaşılmaktadır. 80.000 liralık alacak karşıllğında, davalıya 100.000 liralı emre muharrer senet verilmiş ve daval bu senede dayanarak kollektif şirket hakkında icra takibine geçmiştir. Bu arada, şirketin 3. kişilerdeki alacakları üzerine ihtiyati haciz konulmasına dair karar alınmış ve Tarsus Çimento T.A.Ş.deki alacaklar üzerine de haciz konulmuştur. Tarsus Çimento Şirketinden başka bir üçüncü kişide alacak bulunduğuna dair dosyada her hangi bir belge mevcut değildir. Bu bakımdan borçlu kollektif şirketin borca batık olduğu ve icradaki itiraz üzerine davalının alacağının tahsilinin imkansız hale geldiği ve bu yüzden davalının müzayakaya düşürüldü̈̆̈̈ ve borçlunun tehdidi ile alacağından (30.000) lirasını feragate zorlandığı iddiaları da, ispat edilememiştir.", YHGK, E. 1970/84, K. 1971/2, T. 13.1.1971, Kazancı İçtihat Bilgi Bankası. 
Örneğin, ön ödemenin ve teminat mektubunun iadesini sağlamak amacıyla ibra sözleşmesi yapmak zorunda kalan alıcı, ayıplı ifa sebebiyle TBK m. 229 kapsamında uğradığı zararlarını - bir başka sözleşme yapma fırsatını kaçırması sebebiyle kar kaybı, ürünün iadesi sebebiyle liman, gümrük vb. masraflar - talep etmekten mahrum kaldığında, bu zararları ibra sözleşmesi sayesinde tazmin borcundan kurtulan satıcı açısından da aşırı bir menfaat sağlama şartı gerçekleşmiş olur.

Yargıtay aşırı menfaat sağlanıp sağlanmadığının belirlenmesine ilişkin olarak vermiş olduğu bir kararda $^{62} 500.000$ TL alacak için başlatılan takipte haczin durdurulması için fazladan verilen 250.000 TL'lik senette aşırı menfaat olgusunun gerçekleştiğine işaret etmiştir. Öğretide bir görüş ${ }^{63}$ bu karara da atıf yapmak suretiyle, normal şartlarda elde edilecek menfaatten \%50 ve daha fazlası oranında menfaat edilmesi durumunda aşırı menfaat şartının gerçekleştiğinin ayrıca hâkim tarafından bir değerlendirme yapılmasına gerek olmaksızın kabul edilmesi gerektiğini, zira böyle bir durumda aşırı menfaatin gerçekleştiği hususunda tereddüt bulunmadığını, hâkimin elde edilecek menfaatin \%50 oranını aşmadığı durumlarda takdir hakkını kullanabileceğini belirtmektedir.

Bir hakkın veya kanunundan doğan yetkinin tehdit olarak kullanılmasıyla, bir kişi kefil olma, vakıf kurma, mirasın reddi gibi tek tarafa borç yükleyen bir hukuki işlem yapmaya sevkedilmiş ise sağlanan menfaatin aşırı olduğu kabul edilmeli, bu hususta hâkimin bir değerlendirme yapmasına ihtiyaç olmamalıdır ${ }^{64}$.

\section{SONUÇ}

Korkutmanın varlı̆̆ı açısından öncelikle iradesi sakatlanan kişinin bir tehdide maruz kalmış olması gerekir. Bir hakkın veya yetkinin kullanılması söz konusu değilse tehdit hukuka aykırıdır. Tehdidin hukuka aykırılığından anlaşılması gereken kişinin karar verme özgürlügüne müdahale etmenin hukuka aykırı olmasıdır. Bir hakkın veya kanundan doğan yetkinin kanunun öngördüğü kapsam

62 "Davacı, davalıya tapulu taşınmazını haricen satmayı taahhüt ederek 500.000 lira kapora aldığını, sonra bu taşınmazını tapu ile başkasına sattığ üzere davacının evine gidildiğinde davacının borcunu kabul ederek ödeme teklifinde bulunduğu, ancak vaktin geç olması nedeniyle ertesi günü ödemek üzere 500.000 liralık çek vermeyi teklif ettiği ancak alacaklı tarafin bunu kabul etmeyerek daha fazla çek verilmediği takdirde haczi tatbik ettirerek eşyaları birlikte getirdiği hamallarla alıp götüreceklerini bildirmesi üzerine davacının da olayı, o sırada evde bulunmayan annesinin ve komşuların duymaması ve itibarının zedelenmemesi için 250.000 liralık daha çek verdiği, davalı tarafin bu çekleri ertesi gün bankadan tahsil ettiği dosyadaki belgeler ve dinlenen tanı beyanları ile sabit olmuştur. Davacı, davalının kendisinden fazla olarak alınan paradan 247.500 liranın ikrar nedeniyle geri verilmesi için bu davayı açmıştır. Mahkemece davanın kabulüne karar verilmiş, hüküm süresinde davalı tarafindan temyiz edilmiştir.

BK. m. 30/2'ye göre bir hakkın veya kanuni salahiyetin isteneceği ve kullanılacă̆ tehdidi ile müzayakaya duçar olan kimsenin yaptı̆̆ı akit, tehdit eden için fahiş menfaatler temin etmiyorsa bu tehdit ikrahı muteber addolunamaz. Fakat fahiş menfaatler istihsali için tehdit olunan tarafin müzayaka halinde bulunmasından istifade olunmuş olursa bu korku nazara alinir.

Somut olayda yasanın öngördüğü bu koşullar gerçekleşmiş bulunmaktadır. Daval, davacının içinde bulunduğu maddi ve manevi müzayaka halinden yararlanarak ondan fahiş menfaat etmiştir. Öyle ise bu sözleşme B.K. m. 30/2'ye göre geçersiz olup davalı aldığını iade etmek zorundadır.”, Yarg. 13. HD, E. 1982/4652, K. 1982/6044, T. 19.10.1982, Kazancı İçtihat Bilgi Bankası; bkz. BGE 84 II 621.

63 Köroğlu, s. 155.

64 Etter, s. 84; Demirbaş, s. 80. 
ve yöntemle kullanılması durumunda hukuka aykırılık söz konusu olmaz. Bir hak ya da kanundan doğan yetkinin kullanılmasının hukuka aykırılığından söz edilebilmesi için öncelikle kullanılacağı belirtilen bir hak veya kanundan doğan bir yetki bulunmalıdır.

Bir hakkın veya kanundan doğan yetkinin kullanılacağı tehdidi, bu tehdit altında sözleşme yapan kişinin kendisine yönelmiş olmalıdır. Tehdit edilen gerçek kişi olabileceği gibi bir tüzel kişi de olabilir.

TBK m. 38/f.2'ye göre, korkutmanın varlığının kabul edilebilmesi için, bir hakkın veya kanundan doğan yetkinin kullanılacağı tehdidi karşı tarafın zor durumda kalmasına neden olmalıdır. Zor durumda kalmadan anlaşılması gereken tehdit edilenin sözleşmeyi yaparken maddi ya da manevi açıdan şiddetli bir sıkıntı ve çaresizlik hissetmesidir. Zor durumda kalma genellikle mali ya da ekonomik bir sıkıntı içine girme şeklinde ortaya çıar. Bir şirketin zorda kalıp kalmadığı mali verilerinin incelenmesiyle sözleşmenin yapıldığı tarihteki kısa vadeli borç ödeme gücünün tespit edilmesiyle mümkün olabilir.

Bir hak ya da kanundan doğan yetkinin kullanılmasının hukuka aykırılı̆ga neden olan husus tehdit edenin aşırı menfaat sağlamasıdır. Tehdit edenin aşırı bir menfaat sağlayıp sağlamadığını takdir edecek olan hâkimdir. Aşırı menfaat sağlama, tehdit edenin tazminat borcundan kurtulması şeklinde de gerçekleşebilir.

\section{KAYNAKÇA}

Akyol, Şener, Borçlar Hukuku, Genel Hükümler I, İstanbul 1995.

Antalya, O. Gökhan, Marmara Hukuk Yorumu, Borçlar Hukuku Genel Hükümler, Cilt V/1,1, Temel Kavramlar Sözleşmeden Doğan Borç İlişkileri, Genişletilmiş 2. Baskı, Ankara 2019.

Bardakoğlu, Ali, “İkrah”, Türkiye Diyanet Vakfı İslam Ansiklopedisi, 22. Cilt, İstanbul 2000, s. 30-37.

Bucher, Eugen, Schweizerisches Obligationenrecht, Allgemeiner Teil, 2. Auflage, Bern 1988.

Demirbaş, Harun, Türk Borçlar Kanunu’nda Korkutmanın (İkrahın) Şartları ve Sonuçları, Yayımlanmamış Doktora Tezi, İÜSBE, İstanbul 2012.

Eren, Fikret, Borçlar Hukuku Genel Hükümler, 25. Baskı, Ankara 2020.

Ergüne, Mehmet Serkan, Olumsuz Zarar, İstanbul 2008.

Esener, Turhan/Gündoğdu, Fatih, Borçlar Hukuku I, Sözleşmelerin Kuruluşu ve Geçerliliği (TBK m.1-48), İstanbul 2017.

Etter, Josef, Die Furchterregung nach schweizerischem Obligationenrecht, Freiburg 1954.

Gauch, Peter/Aepli, Viktor/Stöckli, Hubert (Hrsg), Präjudizienbuch OR Rechtsprechung des Bundesgerichts (1875-2015), 9. Auflage, Zürich 2016 (Präjudizienbuch OR/Yazar).

Gauch, Peter/Schluep, Walter R./Schmid, Jörg, Schweizerisches Obligationenrecht, Allgemeiner Teil, Band I, 10. Auflage, Zürich 2014.

Gezder, Ümit, Türk/İsviçre Hukukunda Culpa in Contrahendo Sorumluluğu, İstanbul 2009.

Gümüş, Umut, Tolga/Şakar, Zekayi/Akkın, Gürkan/Şahin, Mustafa, "Finansal Analizde Kullanılan Oranlar ve Firma Değer İlişkisi: BİST’de İşlem Gören Çimento Firmaları Üzerine Bir Analiz”, Karadeniz Sosyal Bilimler Dergisi, C. 9, S. 16, 2017, s. 1-23.

Günergök, Özcan/Kayıhan, Şaban, Borçlar Hukuku Dersleri (Genel Hükümler), İstanbul 2020. 
Honsell, Heinrich/Vogt, N. Peter/Wiegand, Wolfgang (Hrsg.), Basler Kommentar zum Schweizerischen Privatrecht, Obligationenrecht I, Art. 1-529 OR, 4. Auflage, Basel 2007 (Basler Komm. OR I/Yazar).

Kılıçoğlu, Ahmet, Borçlar Hukuku Genel Hükümler, Gözden Geçirilmiş-Genişletilmiş 24. Bası, Ankara 2020.

Kocayusufpaşaoğlu, Necip/Hatemi, Hüseyin/Serozan, Rona/Arpacı, Abdülkadir, Borçlar Hukuku Genel Bölüm, Birinci Cilt, Prof. Dr. Necip Kocayusufpaşaoğlu Borçlar Hukukuna Giriş Hukuki İşlem Sözleşme, Yenilenmiş Genişletilmiş Tamamlanmış 4 üncü Bası'dan 7 inci Tipkı Bası, İstanbul 2017.

Köroğlu, Emre, Türk Borçlar Hukukunda İrade Bozukluğu Hallerinden Korkutma, İstanbul 2020.

Meier-Hayoz Artur (Hrsg.), Berner Kommentar, Band VI, 1. Abteilung Allgemeine Bestimmungen, 2. Teilband, Unterteilband 1a, Inhalt des Vertrages, Kommentar zu Art. 19-20 OR, Bern 1991 (Berner Komm. OR/ Yazar).

Nomer, Haluk N., Borçlar Hukuku Genel Hükümler, Gözden Geçirilmiş, Genişletilmiş 17. Bası, İstanbul 2020.

Oğuzman, M. Kemal/Öz, Turgut, Borçlar Hukuku Genel Hükümler, Cilt-1, Güncellenip, Genişletilmiş 18. Bas1, İstanbul 2020.

Öz, Turgut/Acar, Faruk/Gökyayla, Emre/Develioğlu, H. Murat (Editörler Kurulu), İstanbul Şerhi, Türk Borçlar Kanunu, Yürürlük Kanunu, Cilt - 1 (Madde 1-82), İstanbul 2019 (İstanbul Şerhi/Yazar).

Özkaya, Eraslan, Yanılma-Aldatma-Korkutma Davaları (Hata-Hile-İkrah Davaları), Güncellenmiş 4. Baskı, Ankara 2019.

Saymen, Ferit H./ Elbir, Halid K., Türk Borçlar Hukuku, Umumi Hükümler, C. I, İstanbul 1958.

Schmidlin, Bruno, Berner Kommentar zum schweizerischen Privatracht, Obligationenrecht, Allgemeine Bestimmungen, Mängel des Vertragsabschlusses, Art 23-31 OR, 2. Auflage, Bern 2013.

Schwenzer, Ingeborg, Schweizerisches Obligationenrecht, Allgemeiner Teil, 7. Auflage, Bern 2016.

Serozan, Rona, "Culpa in Contrahendo", "Akdin Müsbet İhlâli” ve "Üçüncü Kişiyi Koruyucu Etkili Sözleşme" Kurumlarının Ortak Temeli: Edim Yükümlerinden Bağımsız Borç İlişkisi, İÜMHAD, C. 2, S. 3, 1968, s. $108-129$.

Tekin, İbrahim, Finansal Analiz Teknikleri ve Finansal Analiz Üzerine Bir Uygulama, Adıyaman Üniversitesi Sosyal Bilimler Enstitüsü, Yayımlanmamış Yüksek Lisans Tezi, 2017.

Tekinay, S. Sulhi/ Akman, Sermet/Burcuoğlu, Haluk/Altop, Atilla, Tekinay Borçlar Hukuku Genel Hükümler, Yeniden Gözden Geçirilmiş ve Genişletilmiş Yedinci Baskı, İstanbul 1993.

Tenker, Nejat/Akdoğan, Nalan, Finansal Tablolar ve Mali Analiz Teknikleri, 13. Baskı, Ankara 2010.

Tercier, Pierre/Pichonnaz, Pascal/Develioğlu, H. Murat, Borçlar Hukuku Genel Hükümler, 2. Baskı, İstanbul 2020.

Tunçomağ, Kenan, Türk Borçlar Hukuku, I. Cilt, Genel Hükümler, Altıncı Bası, İstanbul 1976.

von Tuhr Andreas/Peter Hans, Allgemeiner Teil des Schweizerischen Obligationenrechts, Band I (mit Supplement), 3. Auflage, Zürich 1984.

Yavuz, Nihat, Borçlar Hukuku El Kitabı, Ankara 2018.

Yenisu, Ersin, "Finansal Tabloların Oran Analizi İle İncelenmesi: Adese Örneği”, Aksaray Üniversitesi Sosyal Bilimler Enstitüsü Dergisi, C. 3, S. 1, 2019, s. 19-45.

Yılmaz, Ejder, Hukuk Sözlüğü, Ankara 2006. 